\title{
Photography as a Visual Literacy Tool
}

Sandra Liliana Caicedo Barreto

\begin{abstract}
This article is an attempt to show some theoretical issues founded on how visual literacy processes come about through a photography project. The framework explained is based on Wendy Ewald's literacy through photography study (LTP), and on Freire's reading conception which stare at literacy as a process for social inclusion. Further a literature review, I provide some practical aspects based on a visual literacy experience carried out in a private school in Bogotá. Likewise, I describe some key moments of the visual literacy process that can be developed by an image's viewer. All this process is based on the socio cultural perspective.
\end{abstract}

Key words: Visual literacy, literacy through photography, reading for social inclusion.

\section{Resumen}

Este artículo busca mostrar algunos aspectos teóricos fundamentados en cómo surgen los procesos de lecto escritura visual a través de un proyecto de fotografía. La estructura de trabajo explicada, está basada en el estudio de Wendy Ewald "Lecto escritura a través de la fotografía", y en la concepción de lectura de Freire que presenta la lecto escritura como un proceso para la inclusión social. Más allá de la revisión de literatura, proveo algunos aspectos prácticos basados en una experiencia de lecto escritura visual llevada acabo en un colegio privado de Bogotá. Asimismo describo algunos momentos claves de los procesos de lecto escritura que el observador de una imagen puede desarrollar, basado en una perspectiva socio cultural.

Palabras claves: Lecto escritura visual, lecto escritura a través de la fotografía, lectura para la inclusión social.

* Received: 07-02-06 / Accepted: 30-08-06 


\section{Introduction}

Firstly, I consider as many theoreticians have done, that reading existed before oral and writing communication. Human beings read the world and communicated among them through words. When writing appeared, people learnt to read a different code. Freire and Macedo (1987) stated: "reading the world always precedes reading the word, and reading the word implies continually reading the world" (p.25). It means that literate and illiterate people read the world and the words in order to understand what happen within. Nowadays, the science of education continues looking for strategies in order to enhance reading skills.

As a second point, I realize that literacy exists for communicating. This communicative competence involves being able to understand, interpret, infer, and generate responses starting from reading - either words, images or the world itself-. Likewise, this competence implies using written language appropriately in a context. Being able to tell or retell pieces of information, and to transform information into new texts. From these premises, many tools and strategies are still being developed, for improving literacy teaching in order to communicate accurately what humans want to convey.

Working with photographs involve many implicit intentions such as starting visual literacy guidance, encouraging students to read the world through photographs, and promoting innovative oral and writing responses based on a photography project.

\section{New students. New Questions. New answers}

Students are involved in a visual environment. Since early ages, they have faced the visual world that is around them, and I wanted to take advantage of this phenomenon and enroll students in an innovative literacy journey. I planned a photography project as tool for persuading literacy processes, when students not only read images and write about them, but also communicate their thoughts, beliefs and feelings through their visual productions. This practice is called visual literacy.

In terms of research, it is important to consider that not many studies have been done in our EFL context in this field. This proposal takes into account our citizen context and represents a contribution to the EFL field by scrutinizing 
the processes students go through when engaged in a particular form of visual literacy that is through photographs.

Using photographs as a visual literacy tool is not a definitive answer for resolving all difficulties in literacy processes. However, they are a very interesting option since they involve learners' interests and needs, engage technology, and, encourage the writing processes. I am interested in visual literacy processes, in providing a new atmosphere within the classroom and, based on my students' needs, in promoting teachers and learners' creativity.

\section{Theoretical Issues}

This literature illustrates the coverage of a body of literature based on students' responses when they read photographs reading, in order to identify how visual literacy comes about. The general topic was labeled 'Photography as way to promote visual literacy', and involves four subsequent topics to explore: (1) Reading and writing notions, (2) the concept of visual literacy and the role of the photographs within it, (3) reading photographs as an interpretation of the world, and, (4) the interaction between photographs and students responses. These four ideas coexist and interact with one another, based on my research questions and my interpretation of the readings.

\section{Notions about Reading and Writing}

From a personal point of view, it is not true we have only one life to live, if we learn to read, we can live as many lives as we wish. Reading and writing have private and social connotations, those are skills intimately joined. Freire (1997) suggests that reading is a creative experience where the reader must combine ideas from their surroundings with the text they are reading, in order to acquire a broader perspective. This pedagogue states, "The reading of the word, also a function of a search for text comprehension and thus of the objects contained therein, directs us now to a previous reading of the world... which is based on sensory experience" (p.19). In other words, Freire suggests that in order to understand a certain text, we must have prior knowledge of our environment and to put these new ideas into perspective. This makes the learning a very substantial activity.

On the one hand, reading triggers the relationship between the acquisition of the textual knowledge and the prior perception of the reader's reality, and 
through this process, the reader has to increase her or his understanding of life as a whole. On the other hand, writing prepares us with the essential mental tools to gain a better insight on the material of study. From this point of view, writing and reading serve as a guide to approaching ours and others works from a critical perspective.

From Murillo (2003), Moll et. al, (1992) and Smith's (2001) point of view, literacy is immersed in every scene of our lives. It means literacy is a life style, a tool for growing as a person or society to the extent that it considers students' knowledge. They stated that when we consider the "funds of knowledge" of our learners, we are developing literacy as a real teaching and learning practice where it is possible to express what we are and, where small or big communities can enrich of everyone's contributions.

The purpose of presenting these notions about reading and writing is to determine the kind of literacy that I would like the learners develop. Literacy as a social act is motivated through photographs as visual literacy tools. Reading as social act involves interpreting the world in order to solve problems, to create, complain, ask for and share with the others. Lerner (2001) affirmed that it is important to educate human beings that "are able to read between lines" (P.40) that go beyond the mechanization or the copy. She also proposed a literacy programs that promotes creativity and authenticity in the productions and organizes and reflects on learners' thought.

\section{Visual Literacy}

The first concept of visual literacy comes from Debes (1969) who played an imperative role as leader of the team behind 'Visuals are a Language' which included educators and other professionals. He defined visual literacy as:

"A group of vision-competencies that a human being can develop by seeing and at the same time having and integrating other sensory experiences. The development of these competencies is fundamental to normal human learning. When these competencies are developed, they enable a visually literate person to discriminate and interpret the visible actions, objects, symbols, natural or man-made, that he encounters in his environment. Through the creative use of these competencies, he is able to communicate with others. Through the appreciative use of these competencies, he is able to comprehend and enjoy the masterworks of visual communication" (P.27). 
This definition includes two important elements for this research. The first one is that human beings can develop visual competences when they see and bring to mind personal experiences. The second one is, through the development of these competencies, a person can understand better what she/ he sees in the world. Taking into account these elements, the current research pretends to characterize the visual literacy process that students develop using photography as a tool.

Under the idea that images are a language, Benedict (1989) defined visual literacy as the ability to understand and produce visual messages. Benedict focused on the development of educational programs that could teach students' abilities to evaluate and create visual messages, as well as improving reading and writing skills through the use of visual literacy techniques. In line with Benedict words, this research includes students' visual productions. They are photographs that students themselves took.

The production of visual messages is a new issue in Benedict's definition. Similarly, it occurs with Rezabek (1999), who asserted that visual literacy is the ability to both accurately interpret and create messages that are transmitted through the sense of sight, with an emphasis on using visual communication systems. In this experience the use of photographs includes both functions: (1) to read, understand and interpret them and, (2) to express ideas in terms of visual material, to enable them to relate visual images to meanings beyond the images themselves.

Nelson (1988) and Horton (1983) presented more definitions. The first author pointed out that visual literacy is the approach from many disciplines that: 1) studies the physical processes involved in visual perception; 2) uses technology to represent visual imagery, and; 3) develops intellectual strategies to interpret, understand and argue about what is seen. It means that visual literacy involves the ability to read, interpret, and discuss based on the background of the watchers. The second author defined visual literacy as "the ability to understand (read) and use (write) images and to think and learn in terms of images, i.e., to think visually" (p.99). These definitions shape some ideas such as: visual literacy increases the knowledge of ones' and others' cultures, builds up a relationship between communication and people' backgrounds and develop visual competences.

Making an effort to sum up the common points of the definitions mentioned above, visual literacy is a group of acquired competencies for processing and 
interpreting visual messages, for understanding and appreciating the content and purpose of any image. Likewise, people who develop this ability can analyze, argue and evaluate visual communications. Besides, the visual literate can create visual messages to communicate something to someone. In this experience, the written texts were the mediators to shape what the watchers understand, interpret and analyze about the images seen.

\section{The role of Photographs as Visual Literacy tool}

According to Ewald (1990), photographs are an excellent visual tool for developing reading and writing skills. She considers teaching writing very important in the classroom and uses photos for supporting this task. Ewald (1990) lists and describes two significant procedures for the use of photographs. First, the participants have to learn technical skills for watching photos and exploring them. The second consists on teaching participants to shoot and know the film process. This photographer-educator suggests providing participants with hands-on instruction based on four core themes: selfportrait, family, community, and dreams. Likewise, she recommends asking adolescents to identify and create more points of contact with the world from the classroom.

The use of photography as a way to promote visual literacy goes beyond a warming up activity. Nelson (1988) affirmed: "The majority of information absorbed by human beings is collected by our sense of vision" (p. 4). Although the sense of vision is used constantly in our life, students need an appropriate training to be able to analyze an image. Nelson (1988) added: "when the teacher trains learners to analyze photographic images not only contribute to rebuild historical evidences but generate a durable understanding because of the connections between the past and the present" (p.4). The analysis of photographic images contributes to reinforce knowledge.

Kulcsar (2002) affirmed that photographs and the practice of photography might be used as an experience to increase visual literacy. Children can create their own messages through images and make critical readings of their environment, and finally be visually literate. Kulcsar (2002) also asserted that photographs can be a powerful tool "in this battle for the citizenship" (p.12), therefore they can address a better understanding of the environment, facilitate a bigger and better participation in the society and allow students to learn how 
to manipulate the image instead of the image continuing to manipulate them. "Photography is also one technology that can easily be used to motivate, extend, and transform literacy instruction" (Jackman, 2003 pp.3).

In summary, these photographers, educators and researchers mentioned above, highlight that photography is an excellent pedagogical tool in methodological and visual literacy terms. They provide a singular atmosphere in the classroom and in the school. In terms of motivation, they help learners' attention and encourage them to create new ideas and new writings. As an interdisciplinary resource, photographs can involve topics of academic, scientific or artistic discipline and also allow children to gain general cultural knowledge. In visual literacy terms, the use of photographs involves reading, understanding, interpreting, and expressing ideas beyond the images themselves. They allow to gain meaning from what we see and to be able to communicate meaning to others through the images we create. Now it is possible to understand the importance of the role of photography as visual literacy tool within the classroom and its possible meaningful connection to citizenship.

\section{Reading photographs as an interpretation of the world}

There are many different ways to define what reading is. One of those is Freire and Macedo's (1987) definition who mentioned the 'reading of the world'. Those pedagogues highlighted the strong influence and the importance of the context in learning. Reading the world is possible through our own critical awareness. Every human being needs to recognize her or his own culture and background. Likewise, teachers have to recognize both, their own identity and their students' context. Knowing the context may be the most important element that can help to determine the success in interpreting the world.

When students read the world, they can improve as human beings. The values such as collaboration, integrity, or respect for cultural identity take place "in a social and historical context and not in pure air" (Freire, 1997, p. 308). The context in which learning is delivered affects all aspects of the course's design. Therefore, teachers have to consider the learners context. This includes learner characteristics such as physical features, education, cultural background, expectations, and so on. When students read the world, they improve their ownership sense, but it is better if teachers train them through their own testimony, that is when teachers read the student's world too. 
Likewise, Durrer (2004) reflected on how to read photographs through the reconstruction of their meaning. This professional photographer stated that reading depends on one's background, culture, interests, preferences as well as dislikes. It is significant to draw attention to the story behind the photo, because to know what we look at, is often not necessarily enough to understand a picture. People who watch a photo have to recognize that there is not a right or wrong reading. Also, it is important to know the frame of reference and the context that accompanies the picture, or related with their life experience.

Thibault and Walbert (2003) also affirmed that photographs have a strong power to communicate information, and they have a strong power to communicate misinformation. In order to obtain better benefits in the photography reading process it is significant to take into account asking questions, decoding, evaluating, and responding to photographic images, also considering the content of the photograph and the photographer's intention if it is possible.

In brief, from the visual literacy point of view, I infer that reading had existed before oral and writing communication. I could affirm that reading is natural or even instinctive, but, at the same time, it is learned or a culturally transmitted skill. Reading photographs shape these characteristics: On the one hand, it is a natural skill because we can read them according to our beliefs, our experiences, remembrances, imagination, cultural background, context and natural setting. On the other hand, reading photographs can be learned or culturally transmitted when we ask who, what, where, when and why, or, when we go beyond the visual elements or the composition of the photography. Photograph allows us to read the world from different perspectives and give us the opportunity to create or recreate a story behind and/or beyond the picture.

\section{The interaction between Photographs and Oral and Written responses}

Important studies have demonstrated different connections between written production and photography. For instances, Ewald's research (2002) used photography to facilitate children to express what they thought, felt, dreamt or hoped by means of the writing skill. It was a photography project where children from Africa and South America were the participants. They developed different sessions and reflected about them in a kind of portfolio. The findings of her research have been included in public school curriculums through a program 
called 'Literacy through Photography. The use of photographs generated a lot of anecdotes in children lives, because she used personal album photos and allowed children to take their own pictures.

Lutz (1996) implemented creative writing activities based on student-taken photographs in her writing course. Some students wrote their thoughts just by looking at the photos, others followed some suggestions such as: expressing what the photographer imagined when she or he took the picture or predicting the end of the story. This type of writing seemed to help the students overcome the fears they had toward writing. At the end of the course, the author found that "photography stimulated students' interest and developed creative writing" (p 34). She also expressed that when students developed confidence in their writing ability, she could pay more attention to correct grammar, punctuation, and spelling. It is more interesting for teachers to identify the English deficiencies when students dare to write.

Jackman (2003) affirmed that "photography is a powerful pedagogical tool for reluctant writers" (p.3). Photography is a creative way to give confidence to students in their writing processes. Students can use pictures as a beginning of the process. Even the most unwilling writers might enjoy the opportunity to write about a photo that is important to them. No doubt, photography and narrative texts are conveniently connected.

Briefly, I can say that photographs allow creating and producing oral and written responses. Photographs transmit a message, the practice of writing could become into a formal process of jotting, describing, transcribing, and often transcribing from the smaller pocket notebooks into larger books. A watcher of photos can compare them; invent the context, restore the past and create a future. When this process is done by writing, there are many possible topics and any kind of gender can be developed.

Students can express their own beliefs, interests, feelings, and culture through reading photographs. Darlington (1991) states that the oral or written narrations allows viewers to tell or retell stories, to communicate different points of view, and to include new elements to the reading - people, animals, and imaginary characters- through imagination or personal experiences.

In brief, the interaction with photographs allow to relate personal experiences and describe the ways in which characters talk, act, and move, 
saying what they care for and what they fear. Also, through them, it is possible to explore how the characters are conveyed and to explain how the personalities of the characters affect the scheme of the story. The places or situations where photographs take place can have a powerful effect on the theme in the reading and on the reader's emotions. A visual literate has unlimited possibilities to express opinions, emotions, dream and go on about any image.

The key issues and findings in relation to the literature reviewed, point out to recognize the photographs as an important visual literacy tool which can contribute to improve literacy process and develop argumentation. Using photographs as a visual literacy tool is not a definitive answer for resolving all difficulties in reading and written development. However, they are a very interesting option, since they involve learners' interests and needs, engage technology, and encourage cognitive processes. Photographs provide a new atmosphere in the classroom, involve other disciplines, and promote teachers creativity. Now, it is time to take advantages from the great communicational power that photography has within our classrooms, and encourage our students to develop themselves as visual literates.

The interaction between photographs and oral or written responses is possible because they exist to communicate something. Franco and Gorman (1980) affirmed that images could stimulate interest and could serve as a focal point in developing the ability to observe, analyze in detail, test ideas, and provide items for writing texts. Reading photographs or taking them is a social and intellectual activity and is a visual literacy tool for interpreting the world. Through photographs, learners can have a new and a better experience when they face literacy processes.

\section{A Practical Experience}

As it was mentioned above, the main framework was based on Wendy Ewald's literacy through photography study (LTP). This photographer-educator suggests providing participants with hands-on instruction based on four core themes: self-portrait, family, community, and dreams. Likewise, I adapted these topics to my students' characteristics and defined some activities related to every topic. I developed a systematic instructional planning, which includes different relevant assignments for developing the themes. The next chart, describes my first step toward a visual literacy practice starting from a photography project: 
Framework of the Photography Project for developing Visual Literacy

\begin{tabular}{|c|c|c|c|}
\hline & $\begin{array}{r}\text { PHOTOG } \\
\text { AS } \\
\text { VISUAL L } \\
\text { TO }\end{array}$ & $\begin{array}{l}\mathrm{IY} \\
\mathrm{ICY}\end{array}$ & \\
\hline $\begin{array}{l}\quad \text { Self- Portrait } \\
\text { - They watch on a mirror } \\
\text { and draw their self } \\
\text { portrait. } \\
\text { - Reading their own } \\
\text { images and describing } \\
\text { themselves } \\
\text { - Looking for the way to } \\
\text { take their own picture } \\
\text { Outcome: } \\
\text { - Taking their own photos: } \\
\text { to themselves, to their } \\
\text { significant toys, objects } \\
\text { or collections. } \\
\text { - Autobiography }\end{array}$ & $\begin{array}{l}\text { Family } \\
\text { - How they see their } \\
\text { families } \\
\text { - Use family pictures } \\
\text { - Reading photos of faces, } \\
\text { how people see when they } \\
\text { are happy, upset, angry, } \\
\text { etc. } \\
\text { - Who are the characters in } \\
\text { the pictures? } \\
\text { - Explain what they think } \\
\text { about their family, } \\
\text { feelings, and stories } \\
\text { behind the picture. } \\
\text { Outcome: } \\
\text { - Taking photos to their } \\
\text { relatives } \\
\text { - Write about the family } \\
\text { and the feelings }\end{array}$ & $\begin{array}{l}\quad \text { School } \\
\text { - Symbols of the school } \\
\text { - What do they know } \\
\text { about these symbols? } \\
\text { - What these symbols } \\
\text { represent for them and } \\
\text { for the educative } \\
\text { community } \\
\text { - Creating symbols that } \\
\text { represent what they think } \\
\text { about the school. } \\
\text { - What is the story behind } \\
\text { the symbol? } \\
\text { Outcomes: } \\
\text { - Visual productions: } \\
\text { Drawings and pictures. }\end{array}$ & $\begin{array}{l}\text { City } \\
\text { - The teacher will choose } \\
\text { the photos taking into } \\
\text { account the old and the } \\
\text { modern Bogotá. } \\
\text { - The teacher will choose } \\
\text { the photos about some } \\
\text { special places around the } \\
\text { capital. } \\
\text { Outcomes: } \\
\text { - Composition about the } \\
\text { city. } \\
\text { - Taking photos of the city } \\
\text { or of the neighborhood. }\end{array}$ \\
\hline
\end{tabular}

Starting from this core of themes, I developed different activities and students could be able to start a visual literacy process using photographs. The development of the project was done under two views: (1) visual literacy as a way to read and interpret the world through photographs, and (2) visual literacy as an ability to communicate something to the world through images. On the one hand, the first view was supported on activities like asking students to work on vocabulary in order to describe physical appearance and character, to write anything that came to mind about themselves and share their writings, to read faces, to start their autobiographies, to write about the feelings that a picture evoked etc. On the other hand, the second parts for developing visual literacy processes was supported on activities like drawing their self portraits and using the mirrors in order to fill up graphic organizers, create symbols related to the school, take pictures about themselves, their significant things, friends, places, family, etc. All these activities were completely related to their closer realities. 
I combined three instruments for collecting data. (1) The students' artifacts, which were filed in a folder that contains the written and visual productions. Students included photo albums and the other images they produced for communicating their ideas. (2) The teacher's journal was written at the end of every session, it includes my main reflections. I used informal writing and described in detailed the main events of the sessions. Finally, I used audio -tapes (3) for recording oral responses during discussions. These instruments allowed me to read my students world, their expectations, their family relations, their feelings and communitarian vision. This experience represents just a preliminary step toward a wonderful world of the visual literacy field. I hope to encourage language teachers to take advantage of this visual word in order to generate literate people.

\section{Conclusions}

The procedures carried out allowed me to move toward to the next conclusions: The proposal has been successful because photographs provided a singular atmosphere in the classroom. In terms of motivation: gaining learners attention and encouraging them to take into account more details for writing about their lives. The written productions involved different topics such as the family, the friends, past events and feelings; they also allowed children to know more about themselves.

The way how students involved in the process of taking pictures and writing about them provoked interest for knowing more about participants self history. The photograph itself did not communicate much information about the student context. However, students went beyond physical descriptions and included different topics related to their lives. I noticed that some students achieved to express their feeling, others could recall their past and I recognize that students started a process of self knowing. They are being able to gain meaning from what we see.

This experience has important implications for EFL teachers: First, reading photographs is not a one-way process. Likewise, language development is a slow process and the effect of instruction is gradual and cumulative (Long $\mathcal{E}$ Robinson, 1998). Therefore, visual literacy can come about when learners are exposed to meaningful images. In this case their own portraits that evoke their own reality and lives. 
Students are showing a process where they have discovered hidden details, although they are not still reading between lines. They do not argument enough their opinions or points of view. However, I noticed that they were able to create a texts starting from an image and this is a great step for this proposal.

Using photographs as a visual tool is not a definitive answer for promoting visual literacies processes. However, they became a very interesting option since they involved learners' interests and experiences and, encouraged their writing processes. Self portraits became a communicative tool because they transmitted and provoked meaning. Thus, images can be a powerful research tool for educating students and teachers in the construction and co-construction of knowledge, which is a fundamental element for literacy processes; and as well, self portrait is one way to make visible these same processes.

Finally, literacy is a field in which visual techniques are emerging. I believe that the information presented here has application to the broader field of education, precisely because of its inherent adaptability to cultural contexts. As educator, to learn to characterize the visual literacy process that students go through when reading photographs is the aim. This research provides one means by which other educators may begin to articulate the use of photography as a way to promote literacy, either by reading, interpreting and understanding images or by communicating meaning through them.

\section{References}

Benedict, J. (1989) Visual Literacy Collection, Hayden Library of Arizona State University.

Darlington, S. (1991). "Visual Literacy as the Basis for Writing Experience: A Summer Gifted and Talented Program." Journal of Visual Literacy. 11:2: 77-91.

Debes, J. (1969) "The Loom of Visual Literacy." Audiovisual Instruction. New York: Pitman, 25-27.

Durrer, H. (2004). Reading Photographs. Soundscapes: Online journal on media culture ISSN 1567-7745. Soundscapes.info. Volume 7 / 2004-2005. Summer http://www. icce. rug. nl/oger-bin/contents/authors.cgi

Ewald, W. (1990). Literacy Through Photography. Center for Documentary Studies at Duke University and Dirham Public Schools, North Carolina. Fotofest: Literacy through photography (LTP), Downloaded from www.fotofest.org/literacy.asp

Ewald, W. (September, 2002). I Wanna Take Me a Picture : Teaching Photography and Writing to Children. Detroit. 
Franco, A \& Gorman B. (1980). Art, Artifacts, and Material Culture. View: Visual Inquiry/ Experience in Writing. Yale-New Haven Teachers Institute. Volume II Guide Entry to 80.02.05.

Freire, P \& Macedo, D. (1987). Literacy, reading the word and the world. Bergin \& Garvey.

Freire,P. (1997). A Response. In P. Freire, J. W. Fraser, D. Macedo, T. McKinnon, \& W. T. Stokes (Eds.), Mentoring the Mentor: A Critical Dialogue with Paulo Freire (pp. 275399). New York: Peter Lang Publishing, Inc.

Horton, J. (1983). Visual Literacy and Visual thinking. In L. Burbank \& D. Pett (Eds.), Contributions to the study of visual literacy (pp. 92-106). International Visual Literacy Association.

Jackman, F. (2003). Reading, Writing, \& Digital Photography. Paper presented at by APTE Professional Education Development Group (p.3). Retrieved May 27, Web site: http:// www.portalcomunicacion.com.

Kulcsar, J. (2002). The use of photography as a tool to visual literacy. Senac Brazil. Retrieved May 29, Web site: http://www.portalcomunicacion.com.

Lerner, D. (2001). Leer y escribir en la escuela: lo real, lo imposible y lo necesario. México, D.F., Fondo de Cultura Económica.

Long, M. H., \& Robinson, P. (1998). Focus on form: Theory, research, and practice. In C. Doughty \& J. Williams (Eds.), Focus on form in classroom second language acquisition. Cambridge: Cambridge University Press.

Lutz, C (1996). Photography for Creative Writing. (pp. 22-45). Georgia Military College, Kingsville Naval Air Station, Kingsville, Texas.

Moll, L.C., Amanti, C., Neff, D., \& Gonzalez, N. (1992) Funds of knowledge for teaching: Using a qualitative approach to connect classrooms and homes. Theory into Practices 3. (p.132-141)

Murillo, L. (2003). Educación de Gestión Local: El caso de la experiencia Educativa en la Comunidad Arhuaca de Simunurwa. III Congreso Universitarioi de Etnoeducación. Universidad Distrital Francisco José de Caldas.

Nelson, N. (1988). Journal of Visual Literacy. Editorial Page. Volume 16, Number 1; Spring. Retrieved May 27, 2004, Web site: http://www.cameron.edu/jvl

Rezabek, L. (February, 1999). Importance of Visual Literacy. Paper presented at the annual meeting of the Association foe Educational Communications and Technology. Houston, Texas.

Thibault, M \& Walbert D. (September 2003). Reading photographs using questions to decode, evaluate, and understand photographic images. College Composition and Communication for Language Teaching. Vol. 62, No. 2.

Smith, P.H. (2001). La Inmersión en dos idiomas y los fondos de conocimiento lingüístico. Estudios en Lingüística Aplicada 34, 37-50. 


\section{THE AUTHOR}

Sandra Liliana Caicedo Barreto is a candidate to the masters degree in Applied Linguistics to Teaching English at Universidad Distrital. She currently works at the private school Colegio Jordán de Sajonia as a teacher of English in primary and sixth and seventh grades. She is also a member of the International Reading Association and is trying to become a member of the IVLA International Visual Literacy Association. E-mail: slcaicedo@yahoo.com 